TALK ABOUT SEX 



\section{TALK ABOUT SEX}

The Battles over Sex Education in the United States

With a New Preface

Janice M. Irvine

University of California Press Berkeley Los Angeles London 
University of California Press

Berkeley and Los Angeles, California

University of California Press, Led.

London, England

First paperback printing 2004

(1) 2002 by the Regents of the University of California

Library of Congress Cataloging-in-Publication Data Irvine, Janice $\mathrm{M}$.

Talk about sex : the battles over sex education in the United States / Janice M. Irvine

p. $\mathrm{cm}$.

Includes bibliographical references and index. ISBN 0-520-24329-3 (pbk : alk. paper)

I. Sex instruction-United States.

2. Community and school-United States.

I. Title.

HQ57.5.A3 $178 \quad 2002$

$613.9^{\prime} 07^{\prime} 073-d c 21$

2001058500

Manufactured in the United States of America

$\begin{array}{lllllllll}12 & \text { II } & 10 & 09 & 08 & 07 & 06 & \text { os } & 04\end{array}$

$\begin{array}{llllllllll}10 & 9 & 8 & 7 & 6 & 5 & 4 & 3 & 2 & 1\end{array}$

The paper used in this publication meets the minimum requirements of ANSI/NISO z39. 48-1992 (R 1997) (Permanence of Paper). @ 
To my father,

William A. Irvine 
